\title{
Article
}

\section{Does Being Bored Make Us More Creative?}

Mann, Sandi and Cadman, Rebekah

Available at http://clok.uclan.ac.uk/22263/

Mann, Sandi ORCID: 0000-0002-5005-1055 and Cadman, Rebekah (2014)

Does Being Bored Make Us More Creative? Creativity Research Journal, 26 (2). pp. 165-173. ISSN 1040-0419

It is advisable to refer to the publisher's version if you intend to cite from the work. http://dx.doi.org/10.1080/10400419.2014.901073

For more information about UCLan's research in this area go to

http://www.uclan.ac.uk/researchgroups/ and search for < name of research Group>.

For information about Research generally at UCLan please go to http://www.uclan.ac.uk/research/

All outputs in CLoK are protected by Intellectual Property Rights law, including Copyright law. Copyright, IPR and Moral Rights for the works on this site are retained by the individual authors and/or other copyright owners. Terms and conditions for use of this material are defined in the policies page.

\section{CLoK}

Central Lancashire online Knowledge www.clok.uclan.ac.uk

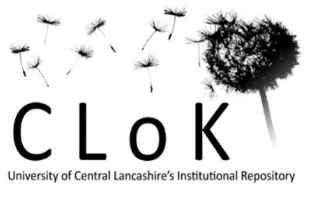


Does being bored make us more creative?

\author{
Sandi Mann and Rebekah Cadman \\ University of Central Lancashire
}

Parts of this paper were presented at the British Psychological Society's Division of Occupational Psychology Annual Conference, January $13^{\text {th }} 2013$

Running head: Does being bored make us more creative?

Submission date: July $2^{\text {nd }} 2012$

Contact details for reprint requests:

Dr Sandi Mann

Senior Lecturer in Occupational Psychology

Department of Psychology

University of Central Lancashire

Preston PR1 2HE

Tel: 01772893441

Fax: 01772892925

smann@uclan.ac.uk 


\begin{abstract}
Boredom has traditionally been associated with a range of negative outcomes, both within the workplace and outside it. More recently, however, it has been suggested that boredom can have positive outcomes, one of which might be increased creativity. This study addressed this proposition by examining the relationship between boredom and creative potential on a range of tasks. Two studies were carried out; the first involved 80 participants taking part in either a boring writing activity or not (control group) followed by a creative task. The second study involved a further 90 participants who varied in the type of boring activity they undertook (either a boring written activity, a boring reading activity or control) and the type of creative task that followed. Results suggested that boring activities resulted in increased creativity and that boring reading activities lead to more creativity in some circumstances (such as convergent tasks) than boring written activities. The role of daydreaming as a mediator between boredom and creativity is discussed and implications are outlined.
\end{abstract}


Contrary to popular wisdom, boredom is not the result of having nothing to do. It is very hard to come up with a situation where a person's options are so limited that he or she literally can do nothing. Rather, boredom stems from a situation where none of the possible things that a person can realistically do appeal to the person in question. This renders the person inactive, and generally unhappy. Thus, boredom is the result of having nothing to do that one likes rather than nothing to do per se. For most people, boredom is a negative experience; even described in one study as 'an extremely unpleasant and distressing experience' (Martin, Sadlo and Stew 2006, p.193).

Some researchers have attempted to define boredom although there is no real consensus. What is agreed about boredom is that it is a 'complex phenomenon' (Martin et al 2006 p.196). Hebb (1996) defined it as a 'state in which the level of stimulation is perceived as unsatisfactorily low' (in Drory 1982, p.141). Lack of external stimulation leads to increased neural arousal in search of variety - failure to satisfy this leads to experience of boredom. Many argue that boredom is a distinct emotional state leading Fisher, one of the forerunners in boredom research, to define boredom as 'an unpleasant, transient affective state in which the individual feels a pervasive lack of interest in and difficulty concentrating on the current activity....[such that] it takes conscious effort to maintain or return attention to that activity' (Fisher 1993, p.396).

Despite the variations in definitions, there is surprising consensus in laypeople's descriptions of the experience of boredom. A qualitative study by Martin et al (2006) reported that all respondents described boredom as 'feeling stressed, agitated, yet at the same time lethargic' (p.208). This concurs with a study of teachers in which respondents described being bored as tiring, miserable and frustrating (Mann 2006). Indeed, boredom has been 
associated with a range of negative outcomes both at work and beyond. Negative consequences at work include: poor work performance (Vodanovich 2003), correlations with anger (Vodanovich 2003), accidents (Branton 1970, Drory 1982), absenteeism (Brisset and Snow 1993), more errors (Cox 1980, Drory 1982, O’Hanlon 1981), stress, increased risk taking/thrill seeking (eg Hamilton 1983), sleepiness (Grose 1989), stress-related health problems e.g heart attacks (eg Alfredsson et al 1982), job dissatisfaction (Caplan et al 1975) and property damage (Drory 1982). Some of these consequences are clearly symptoms of the boredom experience; accidents, mistakes, sleepiness etc. are all the result of being unable to sustain attention. Other consequences are a result of the ways that individuals try to cope with their boredom by either refocusing attention on the task or seeking additional stimulation.

In education, boredom has been linked with diminished academic achievement and school dissatisfaction (eg Maroldo, 1986). For example, students who rated themselves as often bored had generally lower scores on academic tests than those who were sometimes bored (Mikulas \& Vodanovich, 1993). Student boredom has also been shown to be a contributor to truancy (e.g. Watt \& Vodanovich 1999). For example, boredom is one of the most frequently identified causes for students leaving school temporarily (e.g. skipping classes, feigning illness) or permanently (Farmer \& Sundberg 1986, Larson \& Richards 1991). Students who do not miss classes have been shown to have higher performance scores (eg Maroldo, 1986; Farmer \& Sundberg, 1986; Mikulas \& Vodanovich, 1993; Grabe, 2005; Handelsman, Briggs, Sullivan \& Towler, 2005).

\section{Is boredom always bad?}

As the above review suggests, research shows that being bored is generally a negative experience. Yet boredom, like most emotions, has a purpose and, despite widely held views about its negative connotations, it is speculated that there are potentially many benefits to 
being bored. These include that of communicating to others interests, values and beliefs and for communicating lack of 'presence' - that the bored person does not want to be here, functioning as an excuse or justification (Scott \& Lyman 1968) for non-involvement or respite. Boredom might also communicate a desire to be stimulated by others, as well as providing an adaptive mechanism against societal noise or information overload (Klapp 1986). Boredom might also be a 'shield against self-confrontation' (Hoover 1986, p.43); a means to avoid discomfort or new knowledge (Dehlinger 1975).

Like most emotions, boredom is likely to have had evolutionary value; as a stimulus proves itself neither dangerous nor reinforcing, people would simply lose interest in it and turn attention to other stimuli. If humans did not bore of things, it would be impossible to habituate to the continued minutiae of life and everyone would be constantly preoccupied with every minor stimulus to such an extent that they might not attend to real threats.

A final function or benefit of boredom is that it might stimulate the "production of fantasies, awakening creativeness' (Brisset \& Snow 1993, p.243). Boredom is, paradoxically, a motivating force/catalyst for action: "Boredom... is an alerting phenomenon that all is not well and something must be done." (Gaylin 1979 p.129). Boredom might stimulate the need to re-decorate, take up a new hobby or look for a new job. The feeling then, can induce challenge-seeking behaviour and therein lies the paradox that boredom, associated by many with lethargy, can actually be energising, inspiring a search for 'change and variety' (Harris 2000).

\section{Boredom, creativity and daydreaming}

This idea that boredom can lead to a search for 'variety' was taken up by Bell (2011) who suggested that boredom may well boost creativity. When individuals are bored they find 
it difficult to focus their attention on the task and thought processes shift to other areas that can provide more stimulation. When the bored individual cannot physically escape the task to undertake a more engaging one, this attention shift is often from an external focus on the task, to a more internal focus on inner thoughts, feelings and experiences. This inner focus allows a way of gaining the stimulation that is being craved and that is missing from the boring task. This internal focus could involve a search for new ways to carry out the boring task in order to make it more engaging (Toohey, 2011) or could involve thinking about unrelated problems or ideas whose consideration is more appealing than the boring task at hand. It is this attention-shifting that is termed daydreaming and is thus a common by-product of boredom (Smallwood \& Schooler, 2006). Indeed, previous research has shown that individuals use daydreaming to regulate boredom-induced tension (Tushup and Zuckerman 1977), thus suggesting that daydreaming is used as a coping strategy for dealing with the unpleasant state of boredom (Smith 1981).

In concordance with the above, Singer (1975) described daydreaming as shifting attention from the external situation or problem to the internal representation of situations, memories, pictures, unresolved things, scenarios or future goals. Smallwood, more recently explained the process of daydreaming as 'a state of decoupled processing in which attention to ongoing perceptual information is reduced often in favor of the active consideration of internally generated thoughts and feeling' (2011 p.63). Schank (1982) proposed that daydreaming is a part of dynamic memory. Dynamic memory is the ability to re-evaluate information and possible solutions with the re-examining of a problem or unresolved scenario (Schank, 1999). The act of daydreaming can thus provide individuals with the opportunity to re-examine a problem or situation that is preoccupying their mind as many times as they wish, in varied ways and each time incorporating new information and possible solutions. 
The benefit of daydreaming, then is that seemingly illogical ideas can be explored in ways that may not be practically feasible and through this exploration a new or more suitable solution to problems or unresolved situations may be found. This then, can lead to creative problem-solving (Singer, 1981) and suggests a link between daydreaming and creativity (Singer, 1975). This theme was taken up more recently, in an article in Newsweek (2009) which described daydreaming as a 'propitious mental state for creativity, insight and problem solving' (Begley et al 2009) in which 'truly novel solutions and ideas emerge' due to the daydreaming brain being able to bring together unrelated facts and thoughts.

\section{Current Study}

The current studies aimed to explore the hypothesis that boring activities lead to increased creativity. The first study used a boring writing task to induce boredom and a divergent thinking task to measure creative potential. Divergent tasks are where there are no set answers to creative problems but divergent thinkers can come up with a range of novel answers; these are amongst the most common means of assessing creative potential. Divergent thinking tasks require the individual to think creatively by using lateral thinking to produce various solutions to a given problem (Plucker \& Renzulli, 1999) and lend themselves to boredom research given the daydreaming element of boredom (Smallwood et al, 2006).

The writing task might hinder the daydreaming thought to be necessary for creativity to be enhanced, due to it interfering with the propensity for attention to wander. This was suggested by previous research; for example, doodling when bored improved cognitive performance for students and it is thought this was due to it interfering with daydreaming (Andrade 2010). Thus, the second study introduced a boring reading task in addition to the writing task. 
Divergent thinking is not the only form of assessment in creativity, however and has not been without its critiques (Weisberg, 2006). Part of the criticism of divergent thinking as a measure of creative potential has been in the scoring of divergent thinking tasks, in particular with the commonly used method of frequency and uniqueness scoring which simply looks at the number and rarity of the answers - rather than taking into consideration how useful or creative the answers are (Silvia, Winterstein, Willse, Barona, Cram, Hess, Martinez \& Richard, 2008). This can lead to confounding results, as with more answers there is a higher probability of there being unique answers (Silvia et al, 2008). In order to address this limitation both frequency (number of answers) and creative usefulness (in terms of the range of creative uses of the responses that were generated), were assessed independently by two raters as suggested by Silvia et al (2008), were used in the current study. The use of more than one creative divergent thinking task also addressed the concerns that Silvia et al (2008) had in relation to the problems of reliability in using only one task. In addition, Study 2 also introduced a convergent creative task (where there are definite answers to a problem) to further address any possible limitations.

\section{Study 1}

This study was designed to investigate the impact of undertaking a boring writing activity (copying telephone numbers from a phone directory) on subsequent levels of creativity shown in a divergent thinking task (to come up with as many uses for a pair of polystyrene cups as possible). The IV was the pre-creativity activity - either a boring task or not. The DVs were the number of answers produced in the creative potential task and the degree of creative usefulness of those answers. 
The participants were from an opportunity sample from a Community Church local to one of the researchers. No ages were recorded; however, all participants were over 18. There were 80 participants (40 control condition and 40 boredom condition) with an even split of gender for each condition. Two raters were used to assess the level of 'useful creativity' (i.e. the degree of creativity in coming up with different uses of the objects) of the answers provided. These raters were colleagues of one of the authors but blind to the hypotheses of the study.

\section{Materials/Apparatus}

The participants in the boredom condition received an information 'briefing' sheet, pages from a telephone book and a recording sheet on which to write down the telephone numbers. After this, participants in both the boredom and the control conditions underwent the same creative task. Both sets of participants received the same instruction sheet for this task, two polystyrene cups, the recording sheet to write down their list of different uses for the cups and a post procedure information sheet containing the researcher's contact information.

The boredom task was created especially for this study; however, the creative uses task was an adapted version of Guilford's Alternative Uses Brick Task (1967, cited in Silvia et al, 2008), which has been widely used and has become an accepted measure of divergent thinking.

The raters were provided with the instruction sheets briefly explaining the study and the criteria, the participants answer sheets from the creative task and a recording sheet to record the scores. 


\section{Procedure}

The participants in the boredom condition were asked to write down telephone numbers from a phone book for 15 minutes. Once the time had elapsed they were asked to rate how boring they found the activity as a manipulation check, on a 5 point Likert scale (1 $=$ Not Boring, $5=$ Extremely Boring) and participants with scores below 4 did not continue with the study to ensure that the participants were experiencing a boring task.

Participants were also asked to state if they noticed that they daydreamed at any point during the 'boring' task. Only those who admitted to daydreaming continued on to the creative task.

The creative potential task consisted of the participants being given 3 minutes to list as many different uses for the two polystyrene cups they were provided with. Once the 3 minutes had elapsed the participants were asked to circle their two most creative uses of the cups. The participants were then fully debriefed. All the answers were compiled and given to two raters to assess the two most creative answers.

The experimenter was on hand at all times to answer any queries. The rater began by eliminating any duplicate answers from the list and then rated the two most creative answers on a 5 point Likert scale ( $1=$ No Creativity, $5=$ High Creativity $)$. They were assessing the answers for both quality (jn terms of how useful the suggestions were) and how unusual the answers were. They then recorded the average score for the two most creative answers and recorded it on the sheet provided. 


\section{Results}

The mean Kappa coefficient (0.82) revealed a high reliability (Kappa result over 0.70 ) so no alterations were made to the rater procedures. The rater scores were averaged and an overall score was assigned to each participant.

The mean frequency and standard deviation was obtained for the number of answers provided (Table 1).

\section{TABLE 1 HERE}

An independent t-test was used to investigate the mean frequency of the number of answers provided. The results revealed that there was a significant difference between scores for the two conditions $(\mathrm{t}=-4.316, \mathrm{df}=78, \mathrm{p}<0.0005)$ indicating that the number of answers were higher for participants who completed a boredom task followed by the creative task than participants who completed the creative task alone (control condition). This is also confirmed by the mean scores.

\section{TABLE 2 HERE}

An independent t-test was used to investigate the mean creativity of answers provided. The results revealed that there was a non significant difference between scores for the two conditions $(t=-4 . d f=78, p>0.05)$.

Results from Study 1 suggested then that the boring writing task did increase the number of responses produced which is one measure of creative potential; however being bored did not appear to lead to more creative answers. These results led to the adaption of new techniques for Study 2.

\section{Study 2}


The second study attempted to investigate further the hypothesis that boredom leads to enhanced creativity by making changes to the design of Study 1. In Study 2, a second boredom task was introduced (a boring reading task) as well as two extra creative potential tasks (one of which was a convergent task). The extra creative potential tasks were added as a way of ensuring generalizability of findings. It was further predicted that participants' creativity would be higher following the reading boredom task that following the written boring task and the control, because of the greater opportunities for daydreaming afforded by reading over writing (Andrade 2010).

\section{Participants}

Participants were recruited on an opportunistic basis at the same venue as Study 1, but individuals who had taken part in Study 1 were excluded. They were randomly assigned to the various conditions by selecting a time slot. Again no ages were recorded but all participants were over 18. There were 90 participants for Study 2: 30 in the control condition, 30 in the written boredom condition and 30 in the reading boredom condition with an even split of gender for each condition.

\section{Materials/Apparatus}

The participants in the two boredom conditions (written or reading) received an information sheet and pages from a telephone book. Participants in the written boredom condition also received a recording sheet to write down the telephone numbers.

All conditions received an instruction sheet for Creative Potential Task 1 (which was the same task as in Study 1), two polystyrene cups and the recording sheet to write down their list of different uses for the cups. Once Creative Potential Task 1 was completed they 
underwent Creative Potential Task 2 and received an instruction sheet and recording sheet to write a list of different consequences to global narcolepsy (a chronic sleep disorder which can include excessive sleepiness and sleep attacks).

Once Creative Potential Task 2 was completed they moved onto the last task. They received an instruction sheet and recording sheet for Creative Potential Task 3 which consisted of a series of word problems. After all the tasks were completed the participants were given a post procedure information sheet containing the researcher's contact information.

The boredom tasks were created especially for this study, however, the creative uses task was an adaptation from other research. Creative Potential Task 2 was adapted from Christensen, Merrifield \& Guilford's Consequences Task (1953, cited in Furnham, Crump, Batey \& Chamorro-Premuzic, 2009) whilst Creative Potential Task 3, a convergent creative task, was created for this study and adapted from Mednick \& Mednick Remote Associations Test (1962, 1967, cited in Isen, Daubman \& Nowicki, 1987) and involved completing as many answers as possible (in three minutes) to a series of 40 word problems. Participants were permitted to answer them in any order. They consisted of three stimulus words and were asked to generate the fourth word that combined with each of the stimulus words. They could combine to form a compound word/phrase, a shared meaning word or a shared relationship. For example the answer to the three stimulus words 'MEASURE', 'WORM' and 'VIDEO' would be 'TAPE' (tape measure, tape worm and video tape). 
These methods of assessing creative thinking have been widely used as a measure of creativity (Silvia et al, 2008; Furnham et al, 2009; Isen et al, 1987) and by using more than one creative task it increases the reliability of the results (Silvia et al, 2008).

The raters were provided with the instruction sheets that were used in the pilot study, the participants answer sheets and three copies of the recording sheets.

\section{Procedure}

The tasks were conducted in the same manner as in Study 1. The participants in the written boredom condition were asked to write down telephone numbers from a phone book for 15 minutes and in the reading boredom condition were asked to read the telephone numbers for 15 minutes. Once the time had elapsed they were asked to rate the boredom activity on a 5 point Likert scale $(1=$ Not Boring, $5=$ Extremely Boring $)$ and participants with scores below 4 did not continue with the study. Those who rated the task as boring and indicated that they daydreamed continued on to do the three creative potential tasks. Participants in the control condition undertook the three creative potential tasks without either of the telephone numbers tasks.

Before beginning each creative potential task the participants received an instruction sheet. The experimenter on hand to answer any queries. Each task was 3 minutes long and once the time had elapsed they were asked to circle their two most creative answers. Once this was completed they moved on to the next task.

Once all the tasks were completed all the answers were compiled and given to two raters to assess the two most creative answers. This followed the same procedure as Study 1. 


\section{Results}

The mean 'boredom' score (for how boring they found the boredom task) for those that took part in the written boredom task condition was 4.3 whilst the mean score for those taking part in the reading boredom task was 4.5 .

The mean frequency and standard deviation were obtained for the number of answers provided for each of the first two tasks of creative potential and for the number of correct answers in the third creative task (Table 3 ).

\section{TABLE 3 HERE}

A Oneway between subjects Analysis of Variance was conducted for Task 1 to see if the mean number of answers on this Task differed for each of the three conditions. The results revealed a significant effect of condition $\left[\mathrm{F}(2,87)=14.45, \mathrm{p}=0.000, \mathrm{Eta}^{2}=0.25\right]$. Post hoc Bonferroni paired comparisons tests suggested that the written and reading conditions did not differ significantly from each other $(\mathrm{p}=0.062)$ but written differed significantly from the control condition $(\mathrm{p}=0.01)$ and the reading different significantly from the control condition $(\mathrm{p}=0.000)$.

A Oneway between subjects Analysis of Variance was conducted for Task 2 to see if the mean number of answers on this Task differed for each of the three conditions. The results revealed a significant effect of condition $\left[\mathrm{F}(2,87)=36.098, \mathrm{p}=0.000, \mathrm{Eta}^{2}=0.45\right]$. Post hoc Bonferroni paired comparisons tests suggested that the reading and writing conditions differed significantly $(\mathrm{p}=0.000)$ from each other, the reading and control differed significantly $(\mathrm{p}=0.000)$ and that the writing and control differed significantly $(\mathrm{p}=0.003)$. 
A Oneway between subjects Analysis of Variance was conducted for Task 3 to see if the mean number of correct answers on this Task differed for each of the three conditions. The results revealed a significant effect of condition $\left[\mathrm{F}(2,87)=4.334, \mathrm{p}=0.016, \mathrm{Eta}^{2}=\right.$ 0.09]. Post hoc Bonferroni paired comparisons tests suggested that the only significant differences lay between the reading and control conditions $(\mathrm{p}=0.019)$.

The level of creativity of answers given in the creative tasks 1 and 2 was examined next (but not for Task 3 which involved only supplying right or wrong answers); see Table 4.

\section{TABLE 4 HERE}

Two Oneway ANOVAs were performed to investigate the differences between scores for each Task across the three conditions.

The Task 1 ANOVA revealed that there was a significant effect of the condition [F (2, $\left.87)=7.574, \mathrm{p}=0.001, \mathrm{Eta}^{2}=0.15\right)$. Post hoc Bonferroni paired comparisons tests suggested that the control group differed significantly from the written condition ( $\mathrm{p}=0.043)$ and the reading condition $(\mathrm{p}=0.001)$ but that the written and reading conditions did not differ significantly from each other $(\mathrm{p}=0.56)$.

The Task 2 ANOVA revealed that there was a significant effect of the condition [F (2, $\left.87)=11.67, \mathrm{p}=0.000, \mathrm{Eta}^{2}=0.2\right)$. Post hoc Bonferroni paired comparisons tests suggested that the control group differed significantly from the written condition $(p=0.002)$ and the reading condition $(\mathrm{p}=0.000)$ but that the written and reading conditions did not differ significantly from each other $(\mathrm{p}=0.98)$.

\section{Discussion}


The aim of the two studies reported here was to examine the effects of boredom on creative potential. Two different methods of inducing boredom were used (written task in Study 1 and both reading and writing tasks in Study 2) and creative potential was measured with a range of different tasks.

Study 1 revealed that participants came up with significantly more answers to a creative task following a written boredom task than without such a task. However, although more answers were produced following the boring task, these were not judged to actually be more creative. This suggests that being bored can lead to increased creativity in terms of quantity, but not necessarily in terms of quality. This dichotomy could be due to the writing task interfering with the ability to daydream, since the active act of writing is likely to have the role of refocusing attention on the task (and thus inhibiting daydreaming) in accordance with Andrade's 2010 finding that doodling inhibited daydreaming.

Study 2 thus introduced a reading boring task in addition to the written boring task but the results suggested that the number of creative answers and their level of creativity in Task 1, whilst higher for the reading condition, were not significantly higher. This suggests that boring reading tasks do not lead to significantly more creativity (at least for this type of task) than boring writing tasks do and thus suggests that either the written task did not inhibit daydreaming enough for it to effect creativity or that daydreaming is a not as important a moderator of the boredom-creativity link as hypothesised.

However, the boring tasks, whether written or read, did lead to an increase in both the number of creative answers produced in Task 1 as well as their level of creativity (in terms of how useful they were) when compared to the control (non-boring) condition. These findings 
contradict those of Study 1 that found that level of creativity did not significantly increase after the reading boring task and demonstrates the need for more research in the area.

Study 2 also introduced two new creative potential tasks to investigate whether the type of creative task makes a difference. In Task 2, the number of answers (but not their level of creativity) did differ significantly between the reading and writing conditions such that more answers were produced in the reading condition. This supports the idea that fluency (or number of ideas) does not necessarily equate to originality and creativity of those ideas since previous researchers (eg Snyder et al 2004) have suggested that adding more ideas within the same category, is not necessarily as creative as adding new categories; It also lends some support to the hypothesis that boring reading tasks facilitate more daydreaming than boring written tasks - and it is this daydreaming that leads to an increase in creativity. Both conditions also produced significantly more answers than in the control group. Like in Task 1 , these answers were significantly more creative in the two boring conditions than in the control group. The use of Task 2 then, like Task 1, clearly showed a link between boredom and creativity; Tasks 1 and 2, which were both creative uses or divergent tasks showed similar findings in that preceding them with a boring task increased both the number of creative answers and the level of creativity of those answers.

Task 3 was a totally different type of creative task that could produce only right or wrong answers (a convergent task). Here, only the reading boring task and not the written boring task led to a significant increase the number of correct responses. This again lends further support to the hypothesis that writing inhibits daydreaming (Smallwood et al 2006) and that daydreaming is a mediator of boredom and creativity (eg Klinger 1987). It could be that daydreaming is more significant a factor in the stimulation of creative thoughts with 
convergent creative tasks than with the divergent tasks; daydreaming might be more useful in creative problem-solving tasks in which there are finite solutions to be found, than in more imaginative creative tasks where there are infinite possible outcomes.

\section{Implications of Study}

The findings have implications for the way that boredom is viewed both by society at large and by communities such as within the work or education spheres. Until recently, boredom has been viewed as a negative emotion with only negative outcomes, but the current study adds weight to the evidence that suggests that boredom can sometimes be a force for good. This means that it might be a worthwhile enterprise to allow or even embrace boredom in work, education and leisure. On an individual basis, if one is trying to solve a problem or come up with creative solutions, the findings from the current study suggest that undertaking a boring task (especially a reading task) might help with coming up with a more creative outcome.

\section{Limitations and implications for future research}

Within the two studies there was one contradictory finding; in Study 1, the level of creativity in the answers given did not increase (when compared with the control group) following the writing boredom task, but they did when using the same task in Study 2. This suggests the need for further replication using much larger numbers of participants. It would also be useful to explore the role of daydreaming as a mediator of the proposed boredomcreativity link further by more in-depth measurement of daydreaming during boring tasks followed by regression techniques.

It should also be considered that the method of asking respondents to select their own most creative answers might be flawed in that previous research has suggested individuals are 
poor at doing this; asking independent raters to do this might have produced more clarity in the results (Runco, \& Smith, 1992). There may also have been some confusion as how respondents selected their two responses reflecting the most 'creative use' of the cups and how these were subsequently rated by the raters. Previous studies have simply used 'usefulness' of the responses, so introducing the word term 'creative usefulness' may have confused matters such that it cannot be certain that the most useful responses were being selected and rated as oppose to the most creative responses (which might not be the same thing). Usefulness is considered by some to be more important than creativity as ideas that are bizarre and impractical are not always seen as evidence of creativity when compared with ideas that have practical value (Zeng, Proctor and Salvendy 2011).

Future studies could also examine originality of answers which was alluded to in the current study but not objectively measured, or other more objective measures such as those encompassed in Snyder et al's (2004) 'creativity quotient' that incorporates both fluency and flexibility of ideas. Zeng et al (2011) reviewed a range of DT measures of creative potential and concluded that assessing appropriateness and novelty are key.

A further important limitation in Study 2 was in the temporal relation of the three creative tasks with the boredom task. The boredom task was carried out first, then Creative Task 1, then Creative Task 2 then 3. This meant that by Creative Task 3, two creative tasks had intervened since the boring task and this might have negated the effects of the boring task. It would be useful in future studies to precede each creative task with its own boring task.

It is worth mentioning too that all the participants were obtained from one specific place, namely a Church. Although the relationship between religiosity and creativity has rarely been explored in the literature, links between them have been theoretically proposed 
(Zysberg and Schenck 2013), so future research could ensure greater external validity by ensuring a wider mix of participants.

\section{References}

Alfredsson, L., Karasek, R., \& Theorell, T. (1982). Myocardial infraction risk and psychosocial work environment: An analysis of the male Swedish workforce. Social Science Medicine. 16, 463-467.

Andrade J (2010). What does doodling do? Applied Cognitive Psychology; January 2010, Vol. 24 Issue: Number 1 p100-106,

Begley S, Bailey H, Sone D and Interlandi J (2009 Will the BlackBerry Sink The Presidency? Newsweek; 2/16/2009, Vol. 153 Issue 7, p36-39

Bell, G. (2011). The value of boredom. TEDxSydney Conference. Available at: <http://www.youtube.com/watch?v=Ps_YUEIM2EQ> [Accessed November 2011].

Bransford, J.D., \& Stein, B.S. (1993). The Ideal Problem Solver: A Guide for Improving Thinking, Learning \& Creativity. ( ${ }^{\text {nd }}$ Ed.). NY: W.H. Freeman \& Company.

Branton, P. (1970). A field study of repetitive manual work in relation to accidents in the workplace International Journal of Production Research, 8, 93-107.

Brisset, D. \& Snow, R.P. (1993). Boredom: where the future isn't. Symbolic Interaction, 16, $237-256$. 
Cacioppo, J.T., Gardner, W.L., \& Berntson, G.G. (1999). The affect system has parallel and integrative processing components: Form follows function. Journal of Personality and Social Psychology. 76(5), 839-855.

Caplan, R.D., Cobb, S., French, J.R.P., van Harrison, R. \& Pinneau, S.R. (1975). Job demands and worker health. Washington DC: US Department of Health, Education and Welfare.

Cox, T. (1980). Repetitive work. In C.L. Cooper, \& R. Payne (Eds.), Current Concerns in Occupational Stress. (pp. 23-41). UK: John Wiley \& Sons.

Csikszentmihalyi, M. (1990). Flow: The Psychology of Optimal Experience. Steps Towards Enhancing the Quality of Life. NY: Harper Collins.

Csikszentmihalyi, M. (1996). Creativity: Flow and the Psychology of Discovery and Invention. NY: Harper Collins.

Csikszentmihalyi, M. (2000). Beyond Boredom and Anxiety: Experiencing Flow in Work and Play. (25 $5^{\text {th }}$ ed.). San Francisco, CA: Jossey-Bass.

Damrad-Frye, R., \& Laird, J.D. (1989). The experience of boredom: The role of selfperception of attention. Journal of Personality and Social Psychology. 57(2), 315-320.

De Bono, E. (1970). Lateral Thinking: Creativity Step by Step. NY: Harper \& Row. 
De Bono, E. (1993). Serious Creativity: Using the Power of Lateral Thinking to Create New Ideas. NY: Harper Collins.

Dehlinger R (1975) 'The Yawning Student', p.44-54 in Boredom: Root of Discontent and Aggression, edited by Franz Goetzel. Berkely, CA: Grizzly Peak Press

Drory, A. (1982). Individual differences in boredom proneness and task effectiveness at work. Personnel Psychology. 35, 141-151.

Farmer, R., \& Sundberg, N.D. (1986). Boredom proneness: The development and correlates of a new scale. Journal of Personality Assessment. 50(1), 4-17.

Fisher, C.D. (1993). Boredom at work: A neglected concept. Human Relations. 46(3), 395417.

Furnham, A., Crump, J., Batey, M., \& Chamorro-Premuzic, T. (2009). Personality and ability predictors of the 'consequences' test of divergent thinking in a large non-student sample. Personality and Individual Differences. 46, 536-540.

Game, A.M. (2007). Workplace boredom coping: Health, safety and HR implications. Personnel Review. 36, 701-721.

Gaylin W (1979) Feeling Bored pp 113-129 in Feelings: Our Vital Signs edited by W.Gaylin. New York: Harper and Row 
Grabe, M. (2005). Voluntary use of online lecture notes: correlates of note use and note use as an alternative to class attendance. Computers and Education, 44, 409-421.

Grose, V.L. (1989). Coping with boredom in the cockpit before it's too late. Professional Safety. 34(7), 24-26.

Hallowell, E.M. (2007). Crazy Busy: Overstretched, Overbooked, and About to Snap! Strategies for Handling Your Fast-paced Life. NY: Ballantine Books division of Random House Inc.

Hamilton J (1983) Development of interest and enjoyment in adolescence. Part 11. Boredom and psychopathology. Journal of Youth and Adolescence, 12, 363-372

Handelsman, M.M., Briggs, W.L., Sullivan, N. \& Towler, A. (2005). A Measure of College Student Course Engagement. The Journal of Educational Research, 98 (3), 184-191.

Hardy, L., Mullen, R., \& Jones, G. (1996). Knowledge and conscious control of motor actions under stress. British Journal of Psychology. 87, 621-636.

Harris, M.B. (2000). Correlates and characteristics of boredom proneness and boredom. Journal of Applied Social Psychology. 30, 576-598.

Healy S (1984) Boredom, self and culture. Cranbury, NJ: Associated University Presses

Hill, A.B., \& Perkins, R.E. (1985). Towards a model of boredom. British Journal of Psychology. 76(2), 235-240. 
Hill, A. (2011). Boredom is good for you, study claims: Being bored can motivate people to 'engage in prosocial tasks and encourage more meaningful behaviour'. The Guardian [online]. Available from: http://www.guardian.co.uk/science/2011/may/06/boredom-goodfor-you-claims

Hoover M (1986) Extreme individualisation, False Subjectivity and Boredom. Virginia Journal of Sociology 2: 35-51

Isen, A.M., Daubman, K.A., \& Nowicki, G.P. (1987). Positive affect facilitates creative problem solving. Journal of Personality and Social Psychology. 52(6), 112-1131.

Iso-Ahola, S.E., \& Crowley, E.D. (1991). Adolescent substance abuse and leisure boredom. Journal of Leisure Research. 23(3), 260-271.

Joyce, A. (2005). Boredom numbs the work world. The Washington Post [online]. August 10. Available from: http://www.washingtonpost.com/wpdyn/content/article/2005/08/09/AR2005080901395.html.

Karoly, P. (1993). Mechanisms of self-regulation: A systems view. Annual Review of Psychology. 44, 22-52.

Klapp O (1986) Overload and Boredom. New York: Greenwood Press 
Klinger, E. (1987). Imagery and logotherapeutic techniques in psychotherapy. In W.M. Cox (Ed.). Treatment and Prevention of Alcohol Problems: A Resource Manual. (pp 139-156). NY: Academic Press.

Klinger, E. (2009). Daydreaming and fantasizing: Thought flow and motivation. In K.D. Markman., W.M.P. Klein., \& J.A. Suhr. (Eds.). Handbook of Imagination and Mental Stimulation. (pp. 225-240). NY: Psychology Press.

Larson, R. W., \& Richards, M. H. (1991). Daily companionship in late childhood and early adolescence: Changing developmental contexts. Child Development, 62, 284-300

Mann, S. (1999). Hiding What We Feel, Faking What We Don't: Understanding the Role of Your Emotions at Work. London: Vega member of Chrysalis Books Plc.

Mann, S. (2004). People-work: Emotion management, stress and coping. British Journal of Guidance and Counseling. 32(2), 205-221.

Mann, S. (2007). The boredom boom. The Psychologist. 20(2), 90-93.

Mann, S., \& Robinson, A. (2009). Boredom in the lecture theatre: An investigation into the contributors, moderators and outcomes of boredom amongst university students. British Educational Research Journal. 35(2), 243-258.

Maroldo, G.K. (1986). Shyness, boredom, and grade point average among college students. Psychological Reports, 59, 385-398 
Martin, M, Sadlo G and Stew G (2006) The phenomenon of boredom. Qualitative Research in Psychology, 3, 193-211

Mikulas, W.L., \& Vodanovich, S.J. (1993). The essence of boredom. Psychological Record. 43(1), 3-12.

Noppe, L. (1999). Unconscious, In M.A. Runco., \& S.R. Pritzker. (Eds.). Encyclopedia of Creativity. (Vol 2, pp. 673-680). San Diego, London, Boston, NY, Sydney, Tokyo \& Toronto: Academic Press.

O’Hanlon JF (1981) Boredom: practical consequences and a theory. Acta Psychologica 49, $53-82$

Paulson, M.J., Coombs, R.H., \& Richardson, M.A. (1990). School performance, academic aspirations, and drug use among children and adolescents. Journal of Drug Education. 20(4), 289-303.

Persaud, R. (2004). Faking it: The emotional labour of medicine. BMJ Careers [online]. August 28. Available from: http://careers.bmj.com/careers/advice/view-article.html?id=394 [Accessed November 2012].

Phillips, A. (1993). On Kissing, Tickling and Being Bored: Psychoanalytic Essays on the Unexamined Life. Cambridge, MA: Harvard University Press. 
Runco, M. A., \& Smith, W. R. (1992). Interpersonal and intrapersonal evaluations of creative ideas. Personality and Individual Differences, 13, 295-302.

Rupp, D.E., \& Vodanovich, S.J. (1997). The role of boredom proneness in self-reported anger and aggression. Journal of Social Behaviour and Personality. 12(4), 925-936.

Sansone, C., Weir, C., Harpster, L., \& Morgan, C. (1992). Once a boring task always a boring task? Interest as a self-regulatory strategy. Journal of Personality and Social Psychology. 63, 379-390.

Schank, R.C. (1982). Dynamic Memory. Cambridge: Cambridge University Press.

Schank, R.C. (1999). Dynamic Memory Revisited. Cambridge: Cambridge University Press.

Scott, Marvin and Stanford Lyman. 1968. "Accounts." American Sociological Review 31: 4662.

Silvia, P.J., Winterstein, B.P., Willse, J.T., Barona, C.M., Cram, J.T., Hess, K.I., Martinez, J.L., \& Richard, C.A. (2008). Assessing creativity with divergent thinking tasks: Exploring the reliability and validity of new subject scoring methods. Psychology of Aesthetics, Creativity and the Arts. 2(2), 68-85.

Singer, J.L. (1975). The Inner World of Daydreaming. NY: Harper \& Row.

Singer, J.L. (1981). Towards the scientific study of imagination. Imagination, Cognition and Personality. 1(1), 5-28. 
Smallwood J (2011) Mind-wandering while reading: Attentional decoupling, mindless reading and the cascade model of inattention. Language and Linguistics Compass, Vol 5(2), Feb, 2011. pp. 63-77

Smallwood, J.S., \& Schooler, J.W. (2006). The restless mind. Psychological Bulletin, 132, 946-958.

Smith RP (1981) Boredom: a review. Human Factors, Vol 23(3), Jun, 1981. pp. 329-340.

Snyder A, Mitchell J, Bossamaier T and Pallier G (2004) The creativity quotient; an objective scoring of ideational fluency. Creativity Research Journal 16 (4) p,415-420

Snyder, M. (1979). Self-monitoring processes. In L. Berkowitz. (Ed.). Advances in Experimental Social Psychology. (Vol. 12, pp. 85-125). NY: Academic Press.

Svendsen, L. (2005). A Philosophy of Boredom. London: Reaktion Books Ltd.

Toohey, P. (2011). Boredom: A Lively History. New Haven \& London: Yale University Press.

Tushup, Richard J. and Zuckerman, Marvin, (1977) The effects of stimulus invariance on daydreaming and divergent thinking. Journal of Mental Imagery, Vol 1(2),. pp. 291-301

Van Tilburg, W. A. P., \& Igou, E. R. (2011a). On boredom and social identity: A pragmatic meaning-regulation approach. Personality and Social Psychology Bulletin. 37, 1679-1691. 
Van Tilburg, W. A. P., \& Igou, E. R. (2011b). Why bored George helps other: A pragmatic meaning-regulation hypothesis on boredom and prosocial behavior. Manuscript submitted for publication.

Van Tilburg, W. A. P., \& Igou, E. R. (In Press). On boredom: Lack of challenge and meaning as distinct boredom experiences. Motivation and Emotion.

Vodanovich SJ (2003) Psychometric measures of boredom: A review of the literature. Journal of Psychology, 137, p569-595

Vodanovich SJ and Rupp DE (1999) Are procrastinators prone to boredom? Social Behavior and Personality, 27, 11-16

Vogel-Walcutt, J.J., Abich, J., \& Schatz, S. (2012). Boredom in learning. In N. Steel (Ed.), Encyclopedia of the Sciences of Learning. (pp. 477-479). NY \& London: Springer.

Watson, D., \& Tellegen, A. (1985). Toward a consensual structure of mood. Psychological Bulletin. 98, 219-235.

Watt JD and Vodanovich SJ (1992). An examination of race and gender differences in boredom proneness. Journal of Social Behaviour and Personality, 7, 169-175

Weisberg, R.W. (2006). Creativity: Understanding Innovation in Problem Solving, Science, Invention and the Arts. Hoboken, NJ: John Wiley \& Sons Inc. 
Zeng. L, Proctor. RW, and Salvendy. G (2011) Can Traditional Divergent Thinking Tests Be Trustedin Measuring and Predicting Real-World Creativity? Creativity Research Journal, 23(1), 24-37,

Zuckerman, M. (1979). Sensation Seeking: Beyond the Optimal Level of Arousal. Hillsdale, NJ: Erlbaum.

Zysberg. L and Schenk. T (2013) Creativity, Religiosity, and Political Attitudes. Creativity Research Journal; April 2013, Vol. 25 Issue: Number 2 p228-231, 4p

Plucker, J. A. and Renzulli, J. S. (1999). Psychometric approaches to the Study of Human Creativity. In R.J. Sternberg (ed.) Handbook of Creativity, pp. 35-62. London: Cambridge University Press 
Tables

Table 1: Mean Frequency and Standard Deviation Scores for the Number of Answers Provided After Completing a Creative Task Across a Control and Boredom Condition.

\begin{tabular}{|l|l|l|}
\hline & Mean & S.D \\
\hline Control & 7.33 & 2.01 \\
\hline Boredom & 10.63 & 4.4 \\
\hline
\end{tabular}


Table 2: Mean Frequency and Standard Deviation Scores for the Level of Creativity of the Two Most Creative Answers Provided After Completing a Creative Task Across a Control and Boredom Condition.

\begin{tabular}{|l|l|l|}
\hline & Mean & SD \\
\hline Control & 3.58 & 0.68 \\
\hline Boredom & 3.65 & 0.98 \\
\hline
\end{tabular}


Table 3: Mean Frequency and Standard Deviation Scores for the Number of Answers Provided After Completing a Series of Creative Tasks (1, 2 and 3) Across a Control, Written Boredom and Reading Boredom Condition.

\begin{tabular}{|c|c|c|c|c|c|c|}
\hline \multirow{3}{*}{ Task Group } & \multicolumn{5}{|l|}{ Creative Task } & \multirow{2}{*}{ Row Mean } \\
\hline & Task 1 & Task & & Task & & \\
\hline & Mean (S.D.) & Mean & (S.D.) & Mean & (S.D.) & Mean \\
\hline Control & $8.03 \quad(2.83)$ & 6.73 & $(1.95)$ & 6.47 & $(0.82)$ & 7.08 \\
\hline Written Boredom & $10.03 \quad(2.09)$ & 8.70 & $(1.95)$ & 6.97 & $(0.81)$ & 8.57 \\
\hline Reading Boredom & $\begin{array}{ll}11.60 \quad(2.74) \\
\end{array}$ & 11.60 & $(2.71)$ & 7.10 & (1.00) & 10.10 \\
\hline Column Mean & (2.94) & 9.01 & (2.99) & 6.84 & $(0.91)$ & \\
\hline
\end{tabular}


Table 4: Mean Frequency and Standard Deviation Scores for the Level of Creativity of the Two Most Creative Answers Provided After Completing a Series of Creative Tasks (1 and 2) Across a Control, Written Boredom and Reading Boredom Condition.

\begin{tabular}{|c|c|c|c|c|}
\hline & \multicolumn{2}{|c|}{ Task 1} & \multicolumn{2}{|c|}{ Task 2} \\
\hline & Mean & (S.D.) & Mean & (S.D.) \\
\hline Control & 2.67 & $(0.66)$ & 2.73 & $(0.83)$ \\
\hline Written Boredom & 3.17 & $(0.79)$ & 3.47 & $(0.86)$ \\
\hline Reading Boredom & 3.43 & $(0.86)$ & 3.67 & $(0.66)$ \\
\hline Column Mean & 3.09 & $(0.83)$ & 3.29 & $(0.88)$ \\
\hline
\end{tabular}

